\title{
AKSESIBILITAS PENYANDANG DISABILITAS PADA PEMILU TAHUN 2019 DI KABUPATEN WONOSOBO
}

\author{
Syaifurrohman, ${ }^{1)}$ Dewi Erowati ${ }^{2)}$ \\ Magister IImu Politik, Fakultas IImu Sosial dan IImu Politik, Universitas \\ Diponegoro $^{1}$ \\ Program Studi IImu Pemerintahan, Fakultas IImu Sosial dan IImu Politik, \\ Universitas Diponegoro ${ }^{2}$ \\ ipoenk2001@yahoo.co.id ${ }^{1}$ \\ dewi.erowati@live.undip.ac.id ${ }^{2}$
}

\begin{abstract}
Abstrak
Aksesibilitas penyandang disabilitas menjadi bagian penting dalam Pemilu tahun 2019 yang dijamin dan sudah diatur dalam UU 7/2017 tentang Pemilu. Penelitian ini akan mengupas aksesibilitas bagi penyandang disabilitas dan memetakan persepsi dari kalangan disabilitas di Kabupaten Wonosobo yang partisipasi pemilih penyandang disabilitas tergolong rendah yaitu $29,08 \%$. Penelitian ini bertujuan memberikan pemahaman terhadap penyandang disabilitas tentang aksesibilitas dalam pemilu dan sebagai refleksi bagi penyelenggara pemilu, pemerintah dalam mengimplementasian kebijakan. Penelitian ini menggunakan metode kualitatif deskriptif. Pengumpulan data dilakukan secara terbuka, dengan pemilihan informan secara purposive.Penelitian ini diharapkan dapat memberikan pemahaman terhadap aksesibilitas penyandang disabilitas yang sudah semakin baik dan terhindar dari diskriminatif khusunya pada pemilu tahun 2019 di Kabupaten Wonosobo. Penelitian ini akan mengubah paradigma terkait diskriminasi yang timbul dengan adanya asumsi penyandang disabilitas adalah komunitas marginal yang tidak berdaya dan tentunya memberikan strategi terhadap peningkatan partisipasi dalam Pemilu yang akan datang.
\end{abstract}

Kata Kunci: Aksesibilitas, Penyandang Disabilitas, Penyelenggara Pemilu

\begin{abstract}
Accessibility of persons with disabilities is an important part of the 2019 elections which are guaranteed and regulated in Law 7/2017 on Elections. This research will explore accessibility for persons with disabilities and map the perceptions of people with disabilities in Wonosobo Regency whose voter participation of persons with disabilities is low, namely $29.08 \%$. This study aims to provide an understanding of persons with disabilities about accessibility in elections and as a reflection for election administrators, the government in implementing policies. This research uses descriptive qualitative method. Data collection is conducted openly, with the selection of informants purposively. This research is expected to provide an understanding of the accessibility of persons with disabilities that are getting better and avoid discriminatory especially in the 2019 elections in Wonosobo Regency. This research will change the paradigm related to discrimination that arises with the assumption that people with disabilities are marginalized communities who are powerless and certainly provide a strategy for increasing participation in the coming elections.
\end{abstract}

Keywords: Accessibility, Persons with Disabilities, Election Organizers 


\section{PENDAHULUAN}

Indonesia masih mengalami kesulitan terhadap pemenuhan hak pilih bagi penyandang disabilitas(Nasution, 2019). Padahal,cita-cita dari sebagian besar negara demokratis untuk mewujudkan demokrasi yang proporsional dan berkeadilan dalam mengedepankan aspek hukum, politik dan kemanusiaan sebagai satu kesatuan. Oleh sebab itu, Indonesia dalam mewujudkan demokrasi pancasila dapat dibuktikan dengan adanya penyelenggaraan Pemilihan Umum.

Pemilu menjadikan pembeda dengan negara-negara yang tidak menganut paham demokrasi. Pemilu merupakan wujud suksesi kepemimpinan tanpa kudeta dan dipercaya menjadi cara yang ampuh dalam mengganti kepemimpinan tanpa pertumpahan darah, oleh karena itu sangatlah penting pemilu, karena menjadi tolok ukur keberhasilan demokrasi. Proses pemilu di Indonesia merupakan proses yang panjang dari pemilu ke pemilu (Orde Lama, Orde Baru dan Masa Reformasi). Perjalanan pemilu sangatlah dinamis terutama pada masa reformasi dengan adanya pemilihan langsung dan adanya penggabungan antara Pemilu Legislatif dan Pemilu Eksekutif yang pertama kali di Indonesia yang dilaksanakan pada tahun 2019. Melihat pengawasan terhadap Pemilu yang sangat ketat dan terstruktur memungkinkan terselenggaranya Pemilu yang Demokratis, dengan hal tersebut tentulah segala aspek yang berkaitan dengan Pemilu menjadi sorotan berbagai pihak dalam Pemilu tahun 2019.

Wonosobo menjadi salah satu Kabupaten di Provinsi Jawa Tengah yang melaksanakan Pemilu Tahun 2019 dan Partisipasi cukup tinggi yaitu $79,15 \%$ (KPUD Wonosobo, 2019). Tingginya partisipasi ini, apakah juga termasuk partisipasi dari penyandang disabilitas. Lebih jauh lagi penulis akan membahasnya dalam tulisan ini dengan langkah strategis dan praktis yang menjadi rekomendasi dalam penyelenggaraan pemilu dan pemilihan yang akan datang, khusunya pemilihan dan pemilu yang ramah terhadap penyandang disabilitas.

Fasilitas jaminan akses pada penyandang disabilitas terhadap pemilu berupa implementasi hak penyandang disabilitas untuk memilih pada Pemilu. Akan tetapi, berbagai negara yang menganut sistem demokrasi menunjukkan partisipasi disabilitas dalam menggunakan hak pilih masih rendah. Oleh sebab itu, keterlibatan penyandang disabilitas tidak bisa diabaikan, melihat WHO mengestimasikan jumlah difabel sebesar $10 \%$ dari jumlah populasi dunia. Dengan demikian, partisipasi disabilitas di Indonesia memberikan pengaruh besar dalam menentukan perolehan suara terhadap legislatif dan eksekutif (Fati, 2005). Sementara itu, keikutsertaan penyandang disabilitas dalam akses pemilihan masih memiliki beberapa masalah, meski secara hukum internasional disabilitas telah dijamin hak dan kewajibannnya seperti, CRPD (Konvensi Hak-hak Penyandang Disabilitas), sehingga Indonesia yang ikut serta meratifikasi CRPD, sudah seharusnya berkomitmen dalam memberikan fasilitas kepada disabilitas dengan pemberian hak partsipasi dalam berpolitik (Adinda, 2011).

Tulisan ini bertujuan memberikan pemahaman terhadap penyandang disabilitas tentang aksesibilitas dalam Pemilu dan sebagai rujukan bagi pemerintah dan masyarakat dalam mengimplementasian kebijakan. Penulis berusaha membangun sebuah gambaran terkait persamaan hak disabilitas dalam memperoleh akses pada pemilu tahun 2019 dengan memperhatikan literatur-literatur terdahulu. Penelitian tentang aksesibilitas penyandang disabilitas dalam Pemilu telah dilakukan beberapa penulis sebelumnya dan menjadi bahan pertimbangan dalam 
penelitian ini antara lain: Hasil penelitian Hilmi memperlihatkan perlindungan hak politik bagi disabilitas di Indonesia, berasal dari tujuan UUD 1945 (Nasution, 2019). Sementara itu, penelitian Hernimawati menunjukkan partisipasi tuna grahita masih sebatas prosedural dan rendahnya partisipasi disebabkan keterbatasan aksesibilitas dalam Pemilu di Provinsi Riau (Hernimawati, 2019). Selain itu, Merly menunjukkan mahasiswa penyandang disabilitas masih menilai buruk terhadap implementasi perundang-undangan yang telah banyak mengatur aksesibilitas (Merly, 2015). Lebih lanjut, penelitian Fahmi memperlihatkan Pilkada Aceh Tahun 2017 di Kabupaten Aceh Besar belum memenuhi hak-hak politik bagi pemilih penyandang disabilitas(Ichsan, 2018). Penelitian Martini menunjukkan aksesbilitas pemilih Pilkada Jawa Barat masih terdapat kelemahan yaitu minimnya KPU dalam melakukan sosialisasi aksesbilitas untuk pemilih difable (Martini, 2018).

Beberapa penelitian terkait aksesibilitas penyandang disabilitas dalam pemilu telah dikaji oleh beberapa penulis sebelumnya tersebut. Penulis melihat kajian yang akan penulis teliti adalah hal yang baru dengan indikator bahwa penelitian dilakukan di lokus yang berbeda dengan penelitian terdahulu, penelitian dilakukan di Kabupaten Wonosobo, yang memiliki keragaman budaya masyarakat, fokus kajian pada aksesibilitas penyandang disabilitas pada pemilu tahun 2019 yang merupakan penggabungan pemilu legislatif dan eksekutif pertama kali di Indonesia.

\section{METODE}

Penelitianini menggunakan metode kualitatif deskriptif, sebagai prosedur untuk mengamati lisan dan perilaku individu (Moleong, 2016). Dengan demikian, penulis mendeskripsikan dan menganalisis penyelenggaraan Pemiludi Kabupaten Wonosobo.Penelitian ini memfokuskan

Volume 4, Nomor 2, Agustus 2020 pada aksesibilitas penyandang disabilitas dalam pelaksanaan pemilu tahun 2019 di Kabupaten Wonosobo. Agar diperoleh gambaran yang mendalam, digunakanlah pendekatan kualitatif dengan bentuk studi kasus(Yin, 1987). Lokasi penelitian di Kabupaten Wonosobo, pengumpulan data dilakukan dengan wawancara mendalam, observasi dan dokumentasi.

Pengumpulan data dilaksanakan terbuka dan purposive. Informan dipilih berdasarkan tingkat pemahaman dan pengalaman. Adapun jumlah informan sebanyak 2 orang yang terdiri dari mantan anggota panitia pemilihan kecamatan dan pemilih disabilitas. Teknik analisa data merujuk model Miles dan Huberman yang meliputi reduksi data, display data, dan penarikan kesimpulan(Miles \& Huberman, 2014).

\section{LANDASAN TEORI}

Aksesibilitas menjadi indikator kenyamanan untuk mengakses pelayanan publik bagi penyandang disabilitas(Ellis \& Kent, 2011). Selain itu, UU 8/2016 tentang penyandang disabilitas mendefenisikan aksesibilitas adalah kemudahan akses terhadap disabilitas untuk memperoleh kesempatan yang sama. Menyitir Roebyyanto membagi dua macam aksesibilitas yaitu; Pertama, aksesibilitas fisik adalah akses sarana dan prasarana seperti guilding block, tangga ramp, hand rail, lift, tanda - tanda atau signange bagi disabilitas. Kedua, aksesibilitas non fisik merupakan kemudahan dalam mengakses pelyanan informasi seperti, UU, pendidikan, ketenagakerjaan, serta komunikasi dan teknologi bagi disabilitas (Roebyantho, 2006). Oleh sebab itu, Penulis menganalisisaksesibilitas pada Pemilu 2019 dalammenciptakan hak dan kewajiban yang sama untuk menggunakan hak pilih(Nasution, 2019). 


\section{HASIL DAN PEMBAHASAN}

Perjalanan panjang demokrasi di Indonesia menjadi bagian sejarah yang mendewasakan proses demokrasi di negeri ini. Isu HAM akan berkorelasi dengan demokrasi di Indonesia, sebagaimana hubungan pemilu dengan akses bagi penyandang disabilitas pada pemilu 2019 khusunya di Kabupaten Wonosobo. Oleh karena itu berbagai hal akan penulis kaji dalam upaya mendukung tulisan ini.

\section{Penyandang Disabilitas di Indonesia}

UU 8/2016 tentang penyandang disabilitas mengejawantahkan individu yang memiliki keterbatasan fisik, intelektual, mental dalam waktu yang lama, akan mengalami keterbatasan untuk berpartisipasi terhadap lingkungannya. Sementara itu, data disabilitas di Indonesia dikumpulkan BPS, Kemensos, Kemendiknas dan Kemenkes yang masingmasing memiliki perbedaan data, sebab memiliki narasi yang berbeda. Oleh karena itu, data disabilitas diketahui berjumlah 11.580.117 jiwa dengan disabilitas penglihatan $3.474,035$ jiwa, disabilitas fisik 3.010.830 jiwa, disabilitas pendengaran 2.547.626 jiwa, disabilitas mental 1.389.614 jiwa dan disabilitas kronis 1.158.012 jiwa (ILO, 2014).

WHO memperkirakan $10 \%$ dari penduduk Indonesia adalah penyandang disabilitas. Berdasarkan PUSDATIN dari Kemensos, tahun 2010, penyandang disabilitas di Indonesia berjumlah 11.580.117 jiwa dengan disabilitas penglihatan 3.474 .035 jiwa, fisik 3.010 .830 jiwa, pendengaran 2.547.626 jiwa, mental 1.389.614 jiwa dan kronis 1.158.012 jiwa. Sementara itu, Kemenakertrans, mirilis pada 2010 disabilitas berjumlah 7.126.409 jiwa. Selain itu, data disabilitas dari BPS sejak tahun 1980 melakukan sensus dan survei. Dengan demikian pada tahun 2015 terdapat kesulitan fungsional untuk melihat, mendengar, berjalan, menggerakkan tangan atau jari, konsentrasi, terganggunya emosional, gangguan berbicara, memahami/berkomunikasi dengan orang lain dan mengurus diri sendiri. Kondisi tersebut, menunjukkanumur 10 tahun keatas yang mengalami kesulitan fungsional sebesar $8,56 \%$, sehingga persentase disabilitas terbesar yaitu kesulitan melihat $6,36 \%$ dan terkecil, kesulitan mengurus diri sendiri $1,02 \%$. Dengan demikian, jumlah disabilitas perempuan lebih tinggi persentasenya jika dibandingkan dengan laki-laki untuk semua jenis disabilitas (Ismandari, 2019).

Kurangnya validasi data disabilitas telah mengakibatkan implementasi program terkendala. Terlebih lagi, tidak ditemukan data akurat dan spesifik tentang komunitas disabilitas di Indonesia. Data tersebut juga sangat bervariasi karena adanya definisi yang berbeda dari instansi penyedia data, seperti halnya pendefinisian tuna netra yang dimaknai berbeda, seperti Depkes mendefinisikan penglihatan seseorang untuk diklasifikasikan sebagai tuna netra jika individu hanya mempunyai ketajaman penglihatan 20/200, antara lain penglihatan suatu benda pada jarak 20 kaki sebagai disabilitas, padahal penglihatan normal seharusnyaberjarak 200 kaki. Menurut Depsos tuna netra adalah individu yang tidak bisa merasakan indera penglihatan dalam melakukan aktivitas sosial secara normal(Sidik, 2019).

Merujuk Depnas tuna netra sebagai individu yang duduk di jenjang sekolah dengan tingkat penglihatan dalam melihat papan tulis atau buku cetak dari jarak normal. Lebih lanjut, Persatuan Tuna Nutra Indonesia mengasumsikan tuna netra sebagai individu yang tidak memiliki penglihatanatau masih memiliki sedikit penglihatan, namun tidak mampu melihat untuk membaca tulisan berukuran font 12 dalam keadaan cahaya normal (Sidik, 2019). Sebaliknya, BPS mengukur indivudu sebagai tuna netra berdasarkan keterangan dari individu sendiri untuk dijadikan 
informan primer atau dari keluarga sebagai informan sekunder (BPS, 2014). Hal lain terkait persoalan asumsi yang terlihat ketika seorang tuna daksa yang menggunakan kursi roda mungkin tidak bisa menyembunyikan atau menyangkal dirinya adalah penyandang disabilitas, tapi apabila seseorang pincang ataupun luka di lengan dapat disembunyikan bahkan tidak mengakui dirinya penyandang disabilitas sehingga statistik pendisabilitasanya terhadap disabilitas menjadi bias (Komnas. Ham, 2011). Definisi yang bias dari penyandang disabilitas dari Dinas/Instansi dan organisasi mengakibatkan biasnya jumlah dari penyandang disabilitas itu sendiri sehingga dalam pendataan pemilih terkendala yang mengakibatkan data disabilitas yang kurang valid.

Penyandang disabilitas di Kab Wonosobo adalah bagian dari masyarakat inklusif yang keberadaanya dijamin oleh regulasi.Adapun jumlah masyarakat penyandang disabilitas di Kabupaten Wonosobo yang terdata di Dinas Sosial Pemda Kabupaten Wonosobo sebagaimana berikut :

Tabel 1. Penyandang Disabilitas di Kabupaten Wonosobo Tahun 2018

\begin{tabular}{lccc}
\hline $\begin{array}{c}\text { Jenis } \\
\text { Disabilitas }\end{array}$ & Dewasa & Anak & Total \\
\hline Fisik & 1.512 & 247 & 1.759 \\
\hline Intelektual & 562 & 105 & 667 \\
\hline Mental & 493 & 17 & 510 \\
\hline Sensorik & - & - & - \\
\hline Rungu/Wicara & 271 & 17 & 288 \\
\hline Netra & 493 & 17 & 510 \\
\hline Ganda/Multi & 294 & 187 & 481 \\
\hline Total Jiwa & $\mathbf{3 . 6 2 5}$ & $\mathbf{5 9 0}$ & $\mathbf{4 . 2 1 5}$ \\
\hline
\end{tabular}

Sumber: Data Dinsos Kab.Wonosobo 2018

Tabel tersebut memperlihatkan jumlah dari setiap jenis disabilitas yang terdata di Kabupaten Wonosobo : 1) Disabilitas Fisik yaitu penyandang disabilitas dengan kriteria keterbatasan gerak, seperti: amputasi, lumpuh atau kaku yang disebabkan stroke dan kusta, 2)

Volume 4, Nomor 2, Agustus 2020
Disabilitas Intelektual dengan Disabilitas kesulitan untuk berpikir dipengaruhi tingkat kecerdasan dibawah minimum.antara lain: kesulitan belajar, 3) Disabilitas grahita, 4) Disabilitas mental dengan kriteria keterbatasan berpikir, emosi, perilaku dan interaksi sosial, 5) Disabilitas sensorikdnegan klasifikasi terganggunya fungsi dari panca indera, seperti: netra, rungu, dan wicara; 6) Disabilitas ganda antara lain : rungu-wicara atau netra-tuli.

\section{Hak Politik Penyandang Disabilitas}

Negara demokrasi seperti Indonesia berusaha menjamin warga negaranya memperoleh persamaan hak sebagai wujud pelaksanaan UUD RI 1945 pada pasal 27 ayat (2) bahwa setiap warga negara berhak mendapatkan pekerjaan dan kehidupan yang layak. Pasal tersebut, dipahami dengan negara bertanggungjawab terhadap hak konstitusional seperti, hak bebas dari diskriminatif dan ancaman. Termasuk bagi Disabilitas yaitu perlakuan yang sama oleh negara. Serta dalam UU 29/1999 tentang HAM Pasal 42 menegaskan : "Setiap warga negara yang berusia lanjut, disabilitas fisik dan atau disabilitas mental berhak memperoleh perawatan, pendidikan, pelatihan dan bantuan khusus atas biaya-biaya negara, untuk menjamin kebijakan yang layak sesuai dengan martabat kemanusiaanya, meningkatkan rasa percaya diri, dan kemampuan berpartisipasi dalam kehidupan bermasyarakat, berbangsa dan bernegara".

Konsep normatif menjadi landasan paradigma untuk perlakuan khusus bagi disabilitas. Oleh sebab itu, berbagai instrumen internasional seperti pada Konferensi Wina 14-25 Juni 1993, telah melegalkan pranata tindakan khusus atau perlindungan lebih terhadap hak dari disabilitas untuk mengakses kemanfaatan pelayanan publik. Dalam UU 4/1997 pasal 5 berbunyi:"Setiap penyandang disabilitas 
mempunyai hak dan kesempatan yang sama dalam segala aspek kehidupan dan penghidupan".

Ruang lingkup kesamaan hak disabilitas terhadap aspek kehidupan dalam penjelasan pasal 5 antara lain aspek agama, kesehatan, pendidikan, sosial, ketenagakerjaan, ekonomi, pelayanan umum, hukum, budaya, politik, pertahanan keamanan, olahraga, rekreasi, dan informasi, maka dari itu, memaknai hak disabilitas diperlukan peristilahan atau definisi terkait disabilitas. Istilah "Orang Dengan Disabilitas" sebagai terjemahan "Person With Disability" dari Convention on The Right of Person With Disability (CRPD). Istilah orang dengan Disabilitas fokuskan menjadi "Penyandang Disabilitas" atau dapat disebut PD.

Jaminan akan persamaan hak penyandang disabilitas dalam pemilu tahun 2019 dapat tergambarkan dalam partisipasi penyandang disabilitas dan aksesibilitas di TPS bagi pemilih disabilitas dalam Pemilu yang menjadi salah satu syarat pelaksanaan kedaulatan rakyat, pemilu juga tidak akan bisa tanpa adanya partisipasi yang baik dari seluruh warga negara yang sudah memiliki hak memilih. Seperti halnya Indonesia yang menggunkan sistem demokrasi Pancasila, warga negara memperoleh persamaan hak dalam politik. Senada dengan hal tersebut bahwa penempatan disabilitas sebagai pemilih harus diberikan perlakuan khusus dari penyelenggara Pemilu, bahkanseruan Internasional mensyaratkan kualitas penyelenggaraan Pemilu harus adil dan aksesibilitas. Terlebih lagi, perjanjian Internasional Covenant on Civil and Political Rights dari resolusi PBB tentang HAM menetapkan bahwa setiap warga penyandang disabilitas mempunyai hak khusus berupa kemudahan untuk memperoleh pelayanan dan penyediaan sarana dalam

Volume 4, Nomor 2, Agustus 2020 penyelenggaraan Pemilu (Komnas Ham, 2011).

Pemerintah Indonesia telah menerbitkan beberapa peraturan perundangan terkait penyandang disabilitas. Namun masih banyak pasal dari peraturan berbasis sumbangan. UU 39/1999 tentang Hak Asasi Manusia, Pasal 41 ayat (2) menyatakan bahwa setiap orang dengan disabilitas memiliki hak atas fasilitasi dan perlakuan khusus. UU 25/2009 tentang Layanan Publik, Pasal 29 menegaskan penyedia harus memberikan layanan khusus kepada penyandang disabilitas. UU 28/2002 tentang Pembangunan Gedung, mengatur dengan jelas, fasilitas harus aksesibel bagi disabilitas. Lebih lanjut, pasal 27 mengamanatkan fasilitas harus mudah, aman dan menyenangkan, terutama bagi disabilitas. Pemerintah Daerah Kabupaten Wonosobo juga sudah menerbitkan Peraturan untuk pemberdyaan terhadap Disabilitas yaitu, Perda Kab Wonosobo 1/2015 tentang Perlindungan dan Pemenuhan Hak Penyandang Disabilitas. Terbukti kepedulian pemerintah terhadap penyandang disabilitas, dan dalam Bagian Kesembilan Sipil-Politik Pasal 75 Ayat (2) bahwa setiap disabilitas berhak dan berkesempatan untuk memilih dan dipilih.

Hak-hak politik penyandang disabilitas yang sudah terjamin dalam regulasi, mendukung disabilitas untuk mendapatkan haknya. Adapun hal tersebut, juga diperlihatkan adanya aturan terkait perlindungan bagi penggunaan hak pilih baik dalam aturan Perda maupun Peraturan Komisi Pemilihan Umum terkait pemenuhan hak bagi warga negara baik dalam pendataan sebagai pemilih, calon peserta pemilihan, maupun aksesibilitas pemilih penyandang disabilitas yang dituangkan dalam Peraturan KPU yang mengatur bahwa Persamaan hak penyandang disabilitas yang diatur dalam 
peraturan KPU tersebut adalah tentang semua Warga NKRI yang berumur 17 tahun atau sudah kawin berhak memilih tanpa terkeculi (penyandang disabilitas), persyaratan calon peserta, persyaratan menjadi penyelenggara pemilih yang mengakomodir dari penyandang disabilitas dan diaturnya TPS yang ramah disabilitas dan adanya alat bantu tuna netra.

\section{Aksesibilitas Penyandang Disabilitas Di Indonesia}

Penyandang disabilitas adalah bagian dari masyarakat inklusif yang berarti menjadi satu kesatuan dengan masyarakat pada umumnya tanpa adanya perbedaan baik itu dalam hal politik, sosial, ekonomi dan budaya. Oleh karena itu, terkait persamaan hak penyandang disabilitas menjadi sebuah pekerjaan rumah bersama, dimana peningkatan kesadaran dan pemberdayaan terhadap akses bagi penyandang disabilitas adalah hal yang utama(Nasution, 2020).Pentingnya aksesibilitas bagi disabilitas sebagai bentuk jaminan kemandirian dan partisipasi dalam segala bidang kehidupan di masyarakat. Oleh sebab itu, diskursus aksesibilitas memiliki cakupan yang luas dan bukan hanya terkait fasilitas publik, seperti pasar, gedung pemerintah, transportasi, tetapi juga terhadap pelayanan wajib seperti, kesehatan, pendidikan, sosial dan politik.

Seiring itu, akses dan fasilitas umum bagi disabilitas sudah dibangun di beberapa kota di tanah air. Misalnya di trotoar, area publik hingga sarana transportasi. Pembangunan Ramp untuk pengganti tangga atau untuk naik ke transportasi umum, Portals untuk melindungi pengguna kursi roda, terbuat dari besi dan terletak di ujung trotoar, Guiding block yaitu jalur pemandu ubin bergaris lurus dan tekstur bulat, jembatan penyeberangan orang yang bisa dilalui kursi roda, Zebra cross yang aman, ruang publik dan transportasi umum seperti : alat bantu terhadap sarana transportasi, lift prioritas, informasi berupa audio/visual mudah diakses, informasi layanan khusus dan tersedia tombol papan braille, personel terlatih siap layani, ruang tunggu, kursi prioritas dan toilet khusus (Dewi, 2015).

Artikiel ini, membahastentang aksesibilitas pada tahapan pemilu dan penggunaan hak pilih dalam pemilu. Secara spesifik, aksesibilitas pada pemilu tahun 2019 dalam penggunaan hak pilih dilihat dari akses tahapan pemilu, TPS, dan alat bantu terhadap penyandang disabilitas dalam pemilu.

\section{Aksesibilitas Penyandang Disabilitas pada Pemilu tahun 2019 di Kabupaten Wonosobo}

Kabupaten Wonosobo merupakan Kabupaten yang ramah HAM dan perlindungan terhadap Penyandang Disabilitas termasuk baik, berkurangnya diskriminasi terhadap penyandang disabilitas merupakan salah satu wujud pelaksanaanya. Dalam studi-studi disabilitas pada saat ini lebih banyak dilakukan secara sosiologis (social model) terungkap suatu kenyataan yang memprihatinkan. Penyandang disabilitas di mana-mana nyaris selalu diperlakukan tidak manusiawi oleh masyarakatdi tempat mana mereka hidup. Ini tentu bukan suatu kenyataan yang baru. Beragam bentuk kekerasan terhadap penyandang disabilitas sudah berlangsung selama berabad-abad. Oleh karena itu pemerintah berusaha melindungi penyandang disabilitas dari diskriminatif dan ancaman, dengan regulasi yang mengatur hak-hak penyandang disabilitas.

Persamaan hak pemilu tahun 2019 di buktikan dengan didaftarnya penyandang disabilitas dalam Daftar Pemilih pada pemilu tahun 2019. Adapun jumlah yang terdaftar sebagai pemilih sejumlah 1.159 yang tersebar di seluruh Kecamatanpada Kabupaten Wonosobo. Namun, dari jumlah seluruh pemilih disabilitas terdaftar sebagai 
DPT yang ikut memilih berjumlah 337 pemilih (KPUD Wonosobo, 2019). Sementara itu, partisipasi disabilitas hanya $29,08 \%$ dalam menggunakan hak pilihnya atau datang ke TPS pada saat pemungutan suara. Kondisi tersebut,terhitung rendah dibandingkan partisipasi penyandang disabilitas di Kabupaten/ Kota se - Jawa Tengah dari $35 \mathrm{Kab} /$ Kota menunjukkan daerah tertinggi Kota Tegal dengan partisipasi $100 \%$,Kkota Magelang partisipasi $69,92 \%$ dan Kota Semarang partisipasi $59,79 \%$. Sedangkan yang terendah tingkat partisipasi disabilitas yaitu Kab Cilacap $21,79 \%$, Karanganyar $27,75 \%$ dan Kab Wonosobo 29,08\% (KPUD Wonosobo, 2019).

Rendahnya partisipasi pemilih penyandang disabilitas dalam pemilu tahun 2019 di Kabupaten Wonosobo dimungkinkan oleh banyak faktor seperti halnya akses terhadap pendidikan politik, sosialisasi, pendataan pemilih, dan fasilitas TPS yang tidak maksimal (Nasution, 2019). Penyandang disabilitas oleh lingkungan sosialnya cenderung dibuat terisolasi. Keterisolasian itu, yakni keadaan terputus dari relasi-relasi, menempatkan mereka ke dalam kondisi tidak berdaya, semenjak kekuasaan memang diciptakan dalam relasi-relasi.Keadaan terputus dari relasirelasi membuat mereka nyaris tidak memiliki kesempatan dan akses kepada kebutuhan- kebutuhan manusia yang mendasar. Pendidikan, salah satunya, adalah kebutuhan dasar yang penting bagi penyandang disabilitas terutama jika dipersoalkan didalam konteks partisipasi politik.

Pendidikan merupakan hal yang utama, pendidikan manusia yang merdeka dan berdaulat mesti dimulai dari pendidikan rasa-merasai (sensibilitas), yang diabaikan oleh pendidikan kita, untuk mengadopsi dengan benar teknologi serta demokrasi, titik simpulnya adalah pada pendidikan orientasi hasrat (Wibowo, 2017). Hal tersebut, melatari pendidikan politik bagi rakyat perlu ditingkatkan, agar semakin sadar akan hak dan kewajiban sebagai warga negara sehingga ikut serta secara aktif dalam kehidupan kenegaraan dan pembangunan(Nasution, 2019). Begitu pentingnya makna pendidikan politik sebagai upaya pengejawantahan untuk menjawab berbagai tantangan yang akan senantiasa menghadang. Disisi lain sebagai sarana dan media penyaluran aspirasi dan partisipasi masyarakat, pendidikan politik harus pula menciptakan sistem komunikasi timbal balik.

Pendidikan politik memberikan pengetahuan berupa materi-materi yang bersumber dari ideologi bangsa, perjuangan bangsa, nilai, sikap, keterampilan yang akan menambah untuk berkembang dalam dunia yang semakin modern dimana saling ketergantungan antara bangsa-bangsa di dunia meningkat (Naning, 1982). Akses bagi pendidikan politik bagi Penyandang Disabilitas sangat diperlukan untuk merubah stigma bahwa Penyandang disabilitas adalah kaum yang termarginalkan karena dianggap merupakan manusia yang memiliki keterbatasan. Pendidikan politik akan beriringan di lingkungan masyarakat, walau pemerintah tidak melakukukan kegiatan tersebut. Sosialisasi politik sendiri adalah usaha untuk menanamkan nilai-nilai, sikap-sikap, pengetahuan tentang kehidupan politik dapat dialihkan melalui keluarga, kelompokkelompok masyarakat atau organisasiorganisasi politik, maka jika pendidikan politik dibiarkan tanpa perencanaan dan pembinaan jelas, baik dan terpadu akan dapat tumbuh nilai-nilai, sikap-sikap pengetahuan politik yang saling bertentangan (Naning, 1982).

Pendidikan politik inilah yang menjadikan Penyandang Disabilitas lebih berdaya dan mengerti apa yang harus dilakukan, baik itu terkait informasi yang di dapat bahkan kemajuan teknologi yang 
JURNAL ILMIAH MUQODDIMAH:

Jurnal Ilmu Sosial, Politikk Dan Humaniora

$\begin{array}{lrr}\text { harusnya mempermudah } & \text { untuk } \\ \text { berkomunikasi } & \text { dengan } & \text { sesama } \\ \text { Penyandang Disabilitas dan juga } & \text { dengan } \\ \text { masyarakat umum, sehingga dapat }\end{array}$ mewujudkan cita-cita menjadikan sebuah negara yang sejahtera tanpa mengurangi penghargaan bagi Penyandang Disabilitas dengan mengedepankan persamaan hak dalam akses terhadap bentuk pelayanan publik dewasa ini. Pendidikan politik sendiri memberikan wawasan yang luas terutama bagi Penyandang Disabilitas terkait ideologi, politik, sosial dan budaya juga teknologi yang menyertainya, akhirnya fungsimenjadi lebih bermakna apabila penyandang disabilitas mampu menyerap segala informasi dan pengetahun dalam pendidikan politik, disamping menambah kecintaan pada bangsa dan negara juga mencerdaskan Penyandang Disabilitas diharapkan dengan keteraksesan pendidikan politik bagi Penyandang Disabilitas dapat memacu partisipasi dalam pemilu tahun 2019.

Aksesibilitas terhadap pemilihan umum sangat penting untuk menjamin partisipasi penyandang disabilitas. Hal itu harus mulai dipastikan dari tahap-tahap paling awal, seperti sosialisasi dan pendataan. Sosialisasi pemilihan umum di Kabupaten Wonosobo, terutama yang diarahkan kepada penyandang disabilitas pada pelaksanaannya tidak melibatkan keluargadan kerabat serta hanya menjangkau penyandang disabilitas dipusat-pusat pemerintahan dimana telah terbentuk organisasi penyandang disabilitas. Daerah-daerah yang berjarak dengan pusatpemerintahan belum tersentuh. Pendataan yang dilakukan pun diragukan ketepatannya, karena petugas lapangan belum memiliki pengetahuan dan pemahaman yang memadai terkait disabilitas dan penyandang disabilitas itu sendiri. Persoalan ini kembali membawa kita berjumpa dengan pengakuan tentang masih bercokolnya wacana-wacana

Volume 4, Nomor 2, Agustus 2020 negative tentang disabilitas dan penyandang disabilitas.

Disabilitas adalah persoalan yang pribadi sekaligus publik, persoalan yang local sekaligus global. Hubungan-hubungan tersebu tpaling kentara pada kasus perubahan undang-undang atau ratifikasi HAM, pergeseran wacana dan paradigma dalam ilmu pengetahuan, serta dinamika advokasi atas hak-hak penyan dang disabilitas. Semua itu telah memengaruhi masyarakat berbagai belahan bumi, termasuk di Kabupaten Wonosobo. Pada saat bersamaan, dunia social pada level local (masyarakat dan keluarga) pun memainkan peran yang sangat besar dan bersifat menentukan terhadap partisipasi disabilitas terhadap pemilu 2019 di Kabupaten Wonosobo.

Pemilu 2019 menjamin aksesibilitas penyandang disabilitas seperti dalam PKPU No.3 tahun 2019 menegaskan untuk memberi kemudahan bagidisabilitas untuk menggunakan hak pilih. Kegiatan tersebut, seperti TPS mudah di tempuh oleh disabilitas, sehingga kemudahan bagi penyandang disabilitas sudah diatur jelas, dari hasil wawancara dengan salah satu penyandang disabilitas Tuna Netra yang menggunakan hak pilihnya pada pemilu 2019 denganBapak RJ (Penyandang Tuna Netra) menyampaikan bahwa : "Biasane cara-carane kulo kan ditunjukan teng kamar bilik, kulo di takeni ajeng milih sinten, ada saksi dua yang satu menyaksikan, yang satu menunjukkan, alat bantu enten, ning nek ngangge niku kedalon, tempat duduknya bergabung dengan yang umum, teng TPS enten TPS semawi undak-undakan, ning gih sing nyoblos tetep kulo mung disaksikan tiang kalih tanpa mboten dikancani sederek" ("Biasanya tata caranya saya di tunjukkan ke kamar bilik, terus saya di tanyakan mau memilih siapa, ada dua saksi yang satu menyaksikan, yang satu menunjukkan, alat bantu ada, namun kalau memakai itu 
terlalu lama, tempat duduknya bergabung dengan yang umum, di TPS ada tangga naik, tetapi tetap yang mencoblos adalah tetap saya hanya disaksikan dua orang tanpa ditemani oleh keluarga").

Kondisi tersebut, memperlihatkan kondisi TPS dan sebenarnya dalam PKPU No.3 tahun 2019 harus menjamin akses bagi pemilih disabilitas. Terlihat dari yang disampaikan oleh informan bahwa untuk masuk ada tangga yang berundak tentunya menghambat akses gerak bagi disabilitas apalagi apabila dengan menggunakan kursi roda. Dalam PKPU No.3 tahun 2019 pasal 2,3 dan 4. Menegaskan pemilih disabilitas dapat dibantu oleh pendamping. Lebih lainjut, Pendamping dapat berasal dari anggota KPPS atau orang lain atas permintaan Pemilih. Sementara itu, pemilih tunanetra dalam pemberian suara dapat menggunakan alat bantu yang disediakan. Dari keterangan informan bahwa sesampainya di TPS langsung di dampingi oleh dua orang untuk masuk ke bilik suara dan menggunakan hak pilih hanya saja fasilitas berupa alat bantu tuna netra (template) tidak dimanfaatkan. Jadi prosedur di TPS sudah sesuai dengan protokol namun memang karena kendala dari penyandang disabilitas terkait pengetahuan pentingnya penggunaan suara agar dapat mewakili kepentingan penyandang disabilitas kurang dan tentunya asas kerahasiaan menjadi tidak mutlak lagi dengan keterangan dari informan.

Selanjutnya, dari hasil pemantauan oleh penyelenggara pemilu di tingkat kecamatan oleh F (mantan Ketua PPK): "Dari hasil monitoring ke TPS dengan mengambil sampel 10 TPS dari 210 TPS yang ada di kecamatan, ada 3 penyandang disabilitas yang menggunakan hak pilihnya, untuk akses bagi penyandang disabilitas memang di beri akses yang khusus dan lebih diutamakan karena memang keterbatasan kemampuan bagi pengandang disabilitas. alhamdulillah TPS yg kita

Volume 4, Nomor 2, Agustus 2020 pilihkan untuk penyandang disabilitas pun memenuhi syarat baik luas ataupun pelaksanaannya". Jadi berdasarkan informasi dari informan bahwa untuk TPS bagi penyandang disabilitas sudah di sesuaikan dengan kebutuhan bagi penyandang disabilitas hanya saja di tempatkan pada TPS tertentu, sesuai data disabilitas dari DPT pemilu tahun 2019".

Mengingat pentingnya aksesibilitas

bagi penyandang disabilitas dalam pemilihan umum, maka peran semua pihak dibutuhkan khususnya keluarga penyandang disabilitas yang cenderung membutuhkan dukungan keluarga dan kerabat dekat (family support). Perlunya keluarga faham terkait penyediaan akses bagi penyandang disabilitas agar dalam pemilu keluarga dapat mendampingi menggunakan akses yang disediakan.

Proses panjang menuju keterlibatan penyandang disabilitas dalam pemilihan umum sebagian besar berlangsung didalam keluarga,mulai dari penyediaan akses kepada pengetahuan politik yang aktual, diskusi-diskusi sebagai bagian dari proses pengambilan keputusan, dan pendampingan yang perlu terkait akses tempat pemungutan suara. Pengabaian terhadap proses ini, tentu bukan masalah keluarga, tetapi masalah social dalam cakupan yang sangat luas, sehingga bila hendak diselesaikan, ia harus dilakukan secara komprehensif pada semua level.

Pemahaman tentang disabilitas dan penyandang disabilitas memang sangat berpengaruh. Atas dasar pemahaman bahwa penyandang disabilitas tidak memiliki kemampuan untuk membuat keputusan,maka mereka sering digeneralisir sebagai orang yang sakit, sehingga petugas di lapangan memberikan formulir C-3 atau pendamping pemilih untuk mencoblos. Pada titik ini, angka partisipasi penyandang disabilitas akan tercatat, tetapi suaranya tidak digunakan. 
Adapun hal yang paling mendasar bagi penyandang disabilitas adalah keluarga, karena kebanyakan dari penyandang disabilitas menjadi tulang punggung keluarga sehingga masalah ekonomi lebih mendesak daripada masalahmasalah yang lain. Untuk itu keluarga dekat adalah faktor yang penting dalam mendukung sikap dan partisipasi dari penyandang disabilitas tersebut.

Padabagianyang terakhirini, perlu disebutkan adanya hal-hal teknis yang dapat mempengaruhi aksesibilitas penyandang disabilitas, antara lain: materi pemilu (surat suara), lokasi, dan gedung (TPS) yang ramah disabilitas seperti halnya lokasi yang landai untuk jalur kursi roda dan adanya ruang tunggu khusus/ prioritas bagi penyandang disabilitas menjadi faktor-faktor pendukung yang menentukan suatu penyelenggaraan pemilihan umum yang sepenuhnya bias diakses oleh disabilitas.

Penulis memberikan sebuah pemahaman bagaimana dan strategi apa yang perlu dilakukan untuk keteraksesan pemilu bagi penyandang disabilitas di Kabupaten Wonosobo dalam pemilu kedepan, diantaranya perlunya dari sosialisasi yang secara keberlanjutan harus dilakukan semua elemen untuk partisipasi pemilih dapat terukur kuantitas dan kualitasnya. Semua unsur yang terlibat langsung dalam pemilu ini membutuhkan sinergi dalam proses pemilu. Kualitas sangat ditentukan oleh peran unsur tersebut. Jika salah satu unsur saja tidak berperan sesuai fungsinya, sistem pemilu akan pincang dan berpotensi menimbulkan distorsi. Tujuan pemilu sebagai sarana demokrasi pun akan kehilangan esesnsinya. Ada dua aspek pokok dalam peningkatan kualitas pemilu yang mesti dimiliki oleh unsur yang terlibat, yakni pemahaman utuh terhadap aturan penyelenggara pemilu dan ketaatan terhadap aturan yang sudah diatur dalam
UU dan perangkat hukum dibawahnya (Sardini, 2011). Sosialisasi ini juga perlu melibatkan keluarga, bekerja sama dengan komunitas disabilitas berupa penunjukan agen sosialisasi (Relawan Demokrasi) dari setiap komunitas disabilitas yang berfungsi memberikan sosialisasi dan pendidikan politik kepada komunitasnya, fasilitas di TPS pada disabilitas harus sesuai terhadap jenis disabilitas dan tempat tunggu khusus atau prioritas bagi penyandang disabilitas, serta pemerintah memfasilitasi bentukbentuk penyampaian aspirasi untuk menyerap kebutuhan dari disabilitas.

\section{KESIMPULAN}

Penyediaan akses terhadap penyandang disabilitas pada pemilu tahun 2019 di Kabupaten Wonosobo merupakan bentuk fasilitasi dari penyelenggara Pemilu untuk warga berperan serta dalam Pemilihan. Oleh sebab itu,aksesibilitas bagi penyandang disabilitas pada pemilu tahun 2019 di Kabupaten Wonosobo harus mempertimbangkan kebutuhan bagi mereka yang terdata sebagai pemilih penyandang disabilitas secara keseluruhan dalam bentuk keteraksesan informasi tahapan oleh penyandang disabilitas melalui sosialisasi tahapan serta distribusi logistik yang tepat guna dengan maksud menyesuaikan persebaran disabilitas di TPS bersangkutan, tidak hanya template untuk tuna netra namun penting pula bagi penyandang disabilitas lainnya seperti halnya tempat tunggu prioritas, portals, guiding block, kursi roda. Kondisi tersebut adalah bentuk aksesibilitas bagi pemilih berkebutuhan khusus secara keseluruhan. Sehingga sangat diperlukan pemantauan dan evaluasi agar pemberian akses pada penyandang disabilitas dapat di tingkatkan pada masamasa pemilu mendatang. 
JURNAL ILMIAH MUQODDIMAH:

Jurnal Ilmu Sosial, Politikk Dan Humaniora

\section{DAFTAR PUSTAKA}

\section{Buku :}

Adinda, T. (2011). Menggugat Kebijakan dan Pengadaan Fasilitas Umum untuk Difabel. Yayasan Jurnal Perempuan.

Miles, M. B., Huberman, M. \& Saldana. (2014). Qualitative Data Analysis: A Methods Sourcebook. (H. Salmon, Ed.) (3rd ed.). London: SAGE.

Moleong, L. J. (2016). Metodologi Penelitian Kualitatif. Bandung: PT Remaja Rosadkarya Offset.

Naning, R. (1982). Pendidikan Politik dan Regenerasi. Yogyakarta: Liberty.

Komisi Nasional Hak Asasi Manusia. (2011). Marjinalisasi Hak Politik Penyandang Disabilitas. Jakarta: Komnas HAM.

Sardini, N. H. (2011). Restorasi Penyelenggaraan Pemilu di Indonesia. Yogyakarta: Fajar Media Press.

Wibowo, A. S. (2017). Paideia : Filsafat Pendidikan-Politik Platon. Yogyakarta: PT Kanisius.

Yin, R. K. (1987). Case Study Research : Design and Methods. Baverly Hills: Sage Publications.

Jurnal :

Hernimawati. (2019). Prinsip-Prinsip Berdemokrasi Bagi Penyandang Disabilitas Tuna Grahita Pada Pemilihan Umum 2019 di Provinsi Riau. Nakhoda: Jurnal Ilmu Pemerintahan, 18(1), 11-20. https://doi.org/10.35967/jipn

Ichsan, F. A. \& Fadila, F. (2018). Aksesibilitas Tempat Pemungutan Suara (TPS) dan Implikasinya Terhadap Persentase Pemilih Disabilitas (Studi Kasus: Pemilihan Gubernur dan Wakil Gubernur Aceh Tahun 2017 di Kabupaten Aceh Besar). Jurnal IImiah Mahasiswa FISIP Unsyiah, 3(3), 1-15. https://doi.org/http://www.jim.unsyiah.a c.id/FISIP/article/view/8328/3835
Martini, N. (2018). Aksesbilitas Pemilu Bagi Penyandang Disabilitas di Kecamatan Karawang Timur Kabupaten Karawang Pada Pemilihan Gubernur Jawa Barat Tahun 2018. JURNAL POLITIKOM INDONESIANA, 3(2), 163-178. https://doi.org/10.35706/jpi.v3i2.1664

Merly, M. (2015). Aksesibilitas Pemilu 2014 Dan Implikasinya Terhadap Ketahanan Politik (Studi Tentang Persepsi Mahasiswa Penyandang Disabilitas Di Pusat Layanan Difabel UIN Sunan Kalijaga Yogyakarta). JURNAL KETAHANAN NASIONAL, 21(2), 6177. https://doi.org/10.22146/jkn.8123

Nasution, F. A., \& Kushandajani, K. (2019). Partisipasi Politik Masyarakat Kecamatan Medan Maimun pada Pemilihan Gubernur Sumatera Utara Tahun 2018. JPPUMA Jurnal IImu Pemerintahan dan Sosial Politik Universitas Medan Area, 7(2), 227235. Retrieved from https://doi.org/10.31289/jppuma.v7i2.3 015

Nasution, F. A. (2020). Pemberdayaan Pemerintahan Desa Dalam Membuat Peraturan Desa di Desa Bandar Khalipah Kabupaten Deli Serdang. Jurnal IImiah Muqoddimah: Jurnal IImu Sosial, Politikk Dan Humaniora, 4(2), 53-60.

https://doi.org/10.31604/jim.v4i2.2020. $\% 25 p$

Nasution, H. A. (2019). Memilih dan Dipilih, Hak Politik Penyandang Disabilitas Dalam Kontestasi Pemilihan Umum: Studi Daerah Istimewa Yogyakarta. Jurnal HAM, 10(2), 161-178. https://doi.org/10.30641/ham.2019.10. 161-178

Roebyantho, H. (2006). Implementasi Aksesibilitas Non Fisik (Pelayanan Informasi dan Pelayanan Khusus) Bagi Penyandang cacat di Enam Provinsi. Jurnal Penelitian Dan Pengembangan Usaha Kesejahleraan Sosial, 11(1), 
47-58.

https://doi.org/10.33007/ska.v11i1.588

\section{Konferensi Nasional :}

Dewi, P. R. (2015). Aksesibilitas Partisipasi Politik Penyandang Disabilitas dalam Pemilu di Kota Denpasar. Seminar Nasional Fakultas IImu Sosial dan IImu Politik Universitas Terbuka (hal. 543550). Universitas Terbuka.

\section{Website :}

BPS. (2014). Indonesia - Pendataan Potensi Desa 2008. Retrieved June 12, 2020, from https://mikrodata.bps.go.id/mikrodata/in dex.php/catalog/80/datafile/F2/V300

Fati, M. A. (2005). Pilkada dan Perjuangan Kaum Difabel. Retrieved June 5, 2020, from Mitranetra.com.

ILO. (2014). Inklusi Penyandang Disabilitas di Indonesia. Retrieved June 12, 2020, from https://www.ilo.org/wcmsp5/groups/pub lic/---asia/---ro-bangkok/---ilojakarta/documents/publication/wcms_2 33426.pdf
Ismandari, F. (2019). Indonesia Inklusi dan Ramah Disabilitas. InfoDATIN Pusat Data dan Informasi Kementerian Kesehatan RI, 1-8. Retrieved June 10, 2020, from pusdatin.kemenkes.go.id

Komisi Pemilihan Umum Kabupaten Wonosobo. (2019). Laporan Tahapan Pemilu Tahun 2019 KPU Kabupaten Wonosobo. Wonosobo: KPU Kabupaten Wonosobo. Retrieved June 9, 2020, from https://kpud.wonosobokab.go.id/

Komisi Pemilihan Umum Provinsi Jawa Tengah. (2019, Mei 12). Retrived June 12, 2020, from https://jateng.kpu.go.id/2019/05/pen gumuman/hasil-rekap-penghitunganperolehan-suara-tingkat-provinsi/

Sidik, B. (2019). Data Disabilitas yang Membingungkan. Kompas.Id, p. 1. Retrieved from https://kompas.id/baca/riset/2019/12/ 17/data-disabilitas-yangmembingungkan/ 